\title{
Measurement report: Comparison of wintertime individual particles at ground level and above the mixed layer in urban Beijing
}

\author{
Wenhua Wang ${ }^{1,2,3}$, Longyi Shao ${ }^{1}$, Claudio Mazzoleni ${ }^{3}$, Yaowei Li $^{1}$, Simone Kotthaus ${ }^{4}$, Sue Grimmond ${ }^{4}$, \\ Janarjan Bhandari ${ }^{3}$, Jiaoping Xing ${ }^{1,5}$, Xiaolei Feng ${ }^{1}$, Mengyuan Zhang ${ }^{1}$, and Zongbo Shi $^{6}$ \\ ${ }^{1}$ State Key Laboratory of Coal Resources and Safe Mining and College of Geosciences and Surveying Engineering, \\ China University of Mining and Technology, Beijing, 100083, China \\ ${ }^{2}$ School of Resources and Materials, Northeastern University at Qinhuangdao, Qinhuangdao, 066004, China \\ ${ }^{3}$ Atmospheric Sciences Program and Physics Department, Michigan Technological University, Houghton, MI 49931, USA \\ ${ }^{4}$ Department of Meteorology, University of Reading, Reading, RG6 6BB, UK \\ ${ }^{5}$ School of Forestry, Jiangxi Agricultural University, Nanchang, 330045, China \\ ${ }^{6}$ School of Geography Earth and Environmental Sciences, the University of Birmingham, Birmingham, B15 2TT, UK
}

Correspondence: Longyi Shao (shaol@ cumtb.edu.cn)

Received: 3 October 2020 - Discussion started: 30 November 2020

Revised: 3 March 2021 - Accepted: 3 March 2021 - Published: 7 April 2021

\begin{abstract}
Beijing has been suffering from frequent severe air pollution events, with concentrations affected significantly by the mixed-layer height. Major efforts have been made to study the physico-chemical properties, compositions, and sources of aerosol particles at ground level. However, little is known about the morphology, elemental composition, and mixing state of aerosol particles above the mixed layer. In this work, we collected individual aerosol particles simultaneously at ground level ( $2 \mathrm{~m}$ above ground) and above the mixed layer in urban Beijing (within the Atmospheric Pollution and Human Health in a Chinese Megacity, APHHBeijing, 2016 winter campaign). The particles were analyzed offline by transmission electron microscopy coupled with energy dispersive X-ray spectroscopy. Our results showed that the relative number contribution of mineral particles to all measured particles was much higher during non-haze periods $(42.5 \%)$ than haze periods $(18.1 \%)$; in contrast, internally mixed particles contributed more during haze periods $(21.9 \%)$ than non-haze periods $(7.2 \%)$ at ground level. In addition, more mineral particles were found at ground level than above the mixed-layer height. Around $20 \%$ of individual particles showed core-shell structures during haze periods, whereas only a few core-shell particles were observed during non-haze periods $(2 \%)$. The results showed that the particles above the mixed layer were more aged, with a larger proportion of organic particles originating from coal combus-
\end{abstract}

tion. Our results indicate that a large fraction of the airborne particles above the mixed layer come from surrounding areas influenced by coal combustion activities. This source contributes to the surface particle concentrations in Beijing when polluted air is mixed down to the ground level.

\section{Introduction}

Atmospheric aerosols emitted from anthropogenic or natural sources are composed of a variety of chemical components (e.g., organic matter, black carbon, nitrate, sulfate, ammonium, metals, mineral dust) (Merikallio et al., 2011; Guo et al., 2014; Wang et al., 2016; Peng et al., 2016; Shao et al., 2017; Tao et al., 2017). Anthropogenic aerosols have received increasing attention in recent decades due to their effects on climate and the environment. In fact, anthropogenic aerosols affect climate through cloud condensation nuclei activity (Kerminen et al., 2012), hygroscopic growth (Brock et al., 2016), and light scattering and absorption (Jacobson, 2001; Bond and Bergstrom, 2006; Merikallio et al., 2011; China et al., 2013; Peng et al., 2016; Bhandari et al., 2019b). They can also have adverse effects on human health, for example, by carrying toxic and carcinogenic compounds (Chen et al., 2013; Shao et al., 2016, 2017). High concentrations of aerosol particles in urban air can cause cardiovascular, res- 
piratory, and even nervous system diseases (Xia et al., 2018; De Marco et al., 2019; Shou et al., 2019). It is suggested that outdoor air pollution causes 3.3 million premature deaths worldwide each year (Lelieveld et al., 2015). Atmospheric aerosol particles also affect regional and global geochemical cycles as they are transported over long distances (Heald et al., 2006; Li et al., 2017c; Rodriguez-Navarro et al., 2018).

Recently, China has suffered from severe air pollution conditions, like other countries undergoing rapid social and economic development (Huang et al., 2014). In China, urban air pollution is characterized by frequent occurrence of haze events, high $\mathrm{PM}_{2.5}$ mass level, and expanded haze areas (Guo et al., 2014; Huang et al., 2014; Sun et al., 2014). For example, the maximum hourly average $\mathrm{PM}_{2.5}$ mass concentrations in winter in Beijing reached more than $1000 \mathrm{\mu g} \mathrm{m}^{-3}$ (Li et al., 2017a; Zhang et al., 2017), 40 times above the safe level of $25 \mu \mathrm{g} \mathrm{m}^{-3}$ recommended by the World Health Organization (WHO).

As the megacity capital, Beijing has received much attention, being one of the most polluted cities in China. Atmospheric researchers have been studying aerosol particles to understand haze formation in China (Sun et al., 2013; Huang et al., 2014; Zhou et al., 2018b). Measurements and model analyses highlight the key roles of secondary aerosol formation by trace gases (e.g., volatile organic compounds, $\mathrm{SO}_{2}$, and $\mathrm{NO}_{x}$ ) and stagnant meteorological conditions in the regional haze formation (Wang et al., 2013; Guo et al., 2014; Huang et al., 2014).

Because the characterization of aerosol particles is mainly focused on surface level observations, the understanding of aerosol properties at higher altitudes in urban areas is still insufficient (Zhou et al., 2018a). Vertical differences between precursors, oxidants, and temperature gradients might influence gas-particle partitioning and heterogeneous reactions of $\mathrm{N}_{2} \mathrm{O}_{5}$ (Zhou et al., 2018a). Previous measurements at the Institute of Atmospheric Physics (IAP) meteorological tower in Beijing showed complex vertical distributions of particulate matter and gaseous pollutants (Meng et al., 2008; Sun et al., 2015; Wang et al., 2018; Zhou et al., 2018b). However, most of these studies focused on non-refractory submicron species. Research showed that the mixed-layer height (MLH) could explain some of the vertical difference in aerosol particle chemical composition (Sun et al., 2015; Wang et al., 2018; Zhang et al., 2012). For example, vertical distributions of aerosol particles were more uniform during periods with higher MLH (Wang et al., 2018). As heavily increased air pollution could reduce boundary layer heights by diminishing incoming solar energy and therefore by weakening vertical turbulence, near-surface aerosol concentrations become elevated (Petaja et al., 2016). Moreover, the upper-layer particles could influence those below the MLH by downward entrainment or mixing plumes, making the lower-layer particles more complex (Wehner et al., 2010; Platis et al., 2015; Qi et al., 2019). Previous studies showed that the particles above the MLH considerably influenced cloud forma- tion (Carnerero et al., 2018) and showed a strong aerosolradiation effect (Bond and Bergstrom, 2006). The differences in aerosol types at ground level and at higher altitudes could lead to large differences in aerosol direct forcing estimates (Ramanathan et al., 2002; Li et al., 2010). The vertical difference in aerosol particles also increases the uncertainties in the assessment of the climate system (Li et al., 2017b). Therefore, detailed knowledge of the vertical distribution and chemical composition of aerosols is important for understanding the impact on climate and the aerosol evolution process (Zhang et al., 2009; Wang et al., 2018).

Vertical comparisons of individual aerosol particles and their morphologies, mixing states, and elemental compositions are very limited. Transmission electron microscopy (TEM) can provide detailed individual-particle characterization and help to explain heterogeneous reactions and the aging process ( $\mathrm{Li}$ et al., 2016a). In this study, we compare particles simultaneously collected at ground level and above the MLH based on the meteorological tower at the IAP in Beijing as part of the UK-China Atmospheric Pollution and Human Health (APHH) 2016 winter campaign.

\section{Experimental setup}

\subsection{Aerosol sampling}

Individual aerosol samples were collected at the tower division of the IAP, Chinese Academy of Science $\left(39^{\circ} 58^{\prime} \mathrm{N}\right.$, $116^{\circ} 22^{\prime} \mathrm{E}$ ), in Beijing from 1 to 9 December 2016. The site, located between the north 3rd and 4th Ring Roads in Beijing, is influenced by surrounding and regional traffic, and commercial as well as residential activities (Sun et al., 2016). There is a highway $250 \mathrm{~m}$ east of the IAP.

Two DKL-2 single-stage cascade impactors, with a $0.5 \mathrm{~mm}$ diameter jet nozzle and a flow rate of $1 \mathrm{~L} \mathrm{~min}^{-1}$, were used. The sampler collection efficiency is $\sim 100 \%$ at an aerodynamic diameter of $0.5 \mu \mathrm{m}$ if the particle density is $2 \mathrm{~g} \mathrm{~cm}^{-3}$ (Li et al., 2016b). Copper (Cu) TEM grids, coated with carbon film (300 mesh, Tianld Co., Beijing, China), were used to collect the aerosol samples. The sampling duration varied from $30 \mathrm{~s}$ to less than $5 \mathrm{~min}$, depending on the air pollution load. Simultaneous observations at ground level (Z1; $2 \mathrm{~m}$ above ground) and an elevated altitude (Z2;280 m above ground) enabled us to obtain the vertical profile of the particles. The collected samples were stored in a dry plastic tube and placed in an air dryer to minimize particle changes before analysis.

Automatic lidar and ceilometer (ACL) observations of attenuated backscatter were conducted at the site using a Vaisala CL31 sensor. Measurements were corrected to account for instrument-related background and near-range artifacts (Kotthaus et al., 2016). The MLH was derived from profile measurements using the automatic CABAM (Characterising the Atmospheric Boundary layer based on Auto- 
matic lidars and ceilometers Measurements) algorithm (Kotthaus and Grimmond, 2018). Since the TEM samples were collected for less than $5 \mathrm{~min}$, the MLH at 15 min resolution was used to determine whether the $\mathrm{Z} 2$ observations were located within the MLH or above the MLH (Shi et al., 2019).

Samples were obtained during the periods shown (solid dots and dashed lines) in Fig. 1. Detailed sample information is provided in Table 1. Other measurements including $\mathrm{PM}_{2.5}, \mathrm{SO}_{2}, \mathrm{NO}_{2}$, and $\mathrm{O}_{3}$ mass concentrations at ground level were obtained from the Olympic Park monitor site, which is the closest national air quality monitor station to the IAP $(\sim 1.5 \mathrm{~km})$ (Shi et al., 2019). City average temperature $(T)$ and relative humidity $(\mathrm{RH})$ at ground level were obtained from the Ministry of Ecology and Environment of China (https://www.aqistudy.cn/, last access: 31 March 2021). In this study, the particles were all collected in the morning and midnight, when the MLH was the lowest, and the height of the tower could reach the MLH at that time.

\subsection{Individual-particle analysis}

Individual particles were analyzed using a JEOL JEM-2800 TEM at an accelerating voltage of $200 \mathrm{kV}$. The morphology and mixing state of individual particles were determined from the TEM images. Semi-quantitative elemental composition was determined using energy-dispersive X-ray spectroscopy (EDS), by which elements heavier than boron $(Z>5)$ can be detected. $\mathrm{Cu}$ was not included because the TEM grids were made of copper. The EDS collection duration of each individual particle was about $15 \mathrm{~s}$ to reduce damage of particles from the electron beam. For most particles, only one spectrum of each particle was collected, and the spot size of the beam would be adjusted according to the size of the particles. Therefore, we obtained the average elemental compositions of each particle. However, more than one spot per particle was collected if the particles were inhomogeneous particles according to the TEM images. The aerosol particles were not evenly distributed on the TEM grids; the coarser particles occurred near the center, and the finer particles occurred on the periphery. To ensure a representative data analysis, three or four meshes from the center to the periphery were selected and analyzed. The projected areas of individual particles were determined using the Image-J software (Schneider et al., 2012), which was commonly used for counting and measuring the projected area of atmospheric particles acquired by electron microscopes (Unga et al., 2018). First, the grayscale images of the particles were converted into binary images, in which black pixels represented the particles, and white pixels represented the background. The area-equivalent diameters $\left(D_{\text {Aeq }}\right)$ of the particles are calculated by the following formula: $D_{\text {Aeq }}=$ $2 \cdot(A / \pi)^{1 / 2}$, where $A$ is the projected area of the particles shown in the TEM images (Bhandari et al., 2019a). Most of the particles with a diameter larger than $100 \mathrm{~nm}$ were analyzed in this study.

\section{Results and discussions}

\subsection{Mass concentration of air pollutants}

The temporal variations in different air pollutants and meteorological conditions at ground level are shown in Fig. 1. The hourly averaged $\mathrm{PM}_{2.5}$ mass concentration at the Olympic Park monitoring site ranged from 3 to $530 \mu \mathrm{g} \mathrm{m}^{-3}$, with a sample period average of $113.3 \mu \mathrm{g} \mathrm{m}^{-3}$, significantly exceeding the safe level of $75 \mu \mathrm{g} \mathrm{m}^{-3}$ according to the Chinese National Ambient Air Quality Standard (GB3095-2012). The MLH ranged from 54 to $1496 \mathrm{~m}$, with an average of $397 \mathrm{~m}$. The MLH showed obvious diurnal variation. The hourly mean RH ranged from $17 \%$ to $97 \%$, with a $9 \mathrm{~d}$ mean of $50.3 \%$. The RH and $\mathrm{PM}_{2.5}$ were positively correlated (correlation coefficient $=0.75$; Fig. S1) according to the 216 groups of hourly data, suggesting that higher RH favors the formation of haze (Sun et al., 2014; Wang et al., 2016). As expected, RH and temperature were negatively correlated (correlation coefficient $=-0.51$; Fig. S2). The variation trend of $\mathrm{SO}_{2}$ was similar to that of $\mathrm{NO}_{2}$. However, the average concentration of $\mathrm{NO}_{2}\left(83.2 \mu \mathrm{g} \mathrm{m}^{-3}\right)$ was nearly 5.5 times higher than that of $\mathrm{SO}_{2}\left(15.2 \mu \mathrm{g} \mathrm{m}^{-3}\right)$. The concentration of $\mathrm{O}_{3}$ showed a different trend compared with $\mathrm{NO}_{2}$ and $\mathrm{SO}_{2}$ (Fig. 1), with a $9 \mathrm{~d}$ hourly mean concentration of $20 \mu \mathrm{g} \mathrm{m}^{-3}$.

\subsection{Classification and mixing state of individual particles}

Aerosol particles are classified using their morphologies and elemental compositions into seven main types, namely: (1) primary organic aerosols (POAs), (2) sulfur-rich (S-rich) particles, (3) soot particles, (4) mineral particles, (5) metal particles, (6) internally mixed organic and sulfur-rich particles (OP-S), and (7) other mixed particles. The detailed characteristics of each particle type are shown in Table 2.

POA particles are mainly composed of $\mathrm{C}$ and $\mathrm{O}$, usually with a small amount of $\mathrm{Si}, \mathrm{S}, \mathrm{Cl}$, and $\mathrm{K}$. POA particles are relatively stable under the electron beam irradiation. Based on the morphologies, POA particles can be further divided into spherical (Fig. 2a) and irregular shapes (Fig. 2b). They are mainly from the combustion process of biomass and fossil fuel (Li et al., 2016a; Liu et al., 2021).

S-rich particles (Fig. 2c and d) are mainly composed of O, $\mathrm{S}$, and $\mathrm{N}$ and sometimes also contain some amount of K. Srich particles are beam-sensitive and volatilize under strong beam irradiation. S-rich particles generally represent secondary inorganic components (e.g., $\mathrm{SO}_{4}^{2+}, \mathrm{NO}_{3}^{-}$, and $\mathrm{NH}_{4}^{+}$) (Xu et al., 2019).

Soot particles are mainly composed of $\mathrm{C}$, a minor amount of $\mathrm{O}$, and sometimes $\mathrm{Si}$. Soot particles consist of a number of C-dominated spherical monomers less than $100 \mathrm{~nm}$ in diameter (Fig. 2e and $\mathrm{f}$ ) and can be easily identified under highresolution TEM (Buseck et al., 2014; Bhandari et al., 2017). 
Table 1. Sample information and meteorological conditions.

\begin{tabular}{lrrrrrrrrr}
\hline $\begin{array}{l}\text { Sample } \\
\mathrm{ID}^{\mathrm{a}}\end{array}$ & $\begin{array}{r}\text { Date } \\
(2016)\end{array}$ & $\mathrm{Time}^{\mathrm{b}}$ & $\begin{array}{r}\mathrm{PM}_{2.5} \\
\left(\mu \mathrm{g} \mathrm{m}^{-3}\right)\end{array}$ & $\begin{array}{r}\mathrm{SO}_{2} \\
\left(\mu \mathrm{g} \mathrm{m}^{-3}\right)\end{array}$ & $\begin{array}{r}\mathrm{NO}_{2} \\
\left(\mu \mathrm{g} \mathrm{m}^{-3}\right)\end{array}$ & $\begin{array}{r}\mathrm{O}_{3} \\
\left(\mu \mathrm{g} \mathrm{m}^{-3}\right)\end{array}$ & $\begin{array}{r}\mathrm{RH} \\
(\%)\end{array}$ & $\begin{array}{r}T \\
\left({ }^{\circ}\right)\end{array}$ & $\begin{array}{r}\mathrm{MLH} \\
(\mathrm{m})^{\mathrm{c}}\end{array}$ \\
\hline $\mathrm{Z} 1-1$ & $12 / 1$ & $09: 10$ & $12^{\mathrm{d}}$ & 2 & 48 & 37 & 24 & 6 & - \\
$\mathrm{Z} 2-1$ & $12 / 1$ & $08: 40$ & - & - & - & - & - & - & 194 \\
$\mathrm{Z} 1-2$ & $12 / 2$ & $01: 00$ & 110 & 25 & 109 & 3 & 55 & 2 & - \\
$\mathrm{Z} 2-2$ & $12 / 2$ & $01: 00$ & - & - & - & - & - & - & 141 \\
$\mathrm{Z} 1-3$ & $12 / 2$ & $09: 10$ & 24 & 20 & 134 & 2 & 50 & 3 & - \\
$\mathrm{Z} 2-3$ & $12 / 2$ & $08: 40$ & - & - & - & - & - & - & 134 \\
$\mathrm{Z} 1-4$ & $12 / 3$ & $01: 53$ & 142 & 36 & 102 & 6 & 79 & -1 & - \\
$\mathrm{Z} 2-4$ & $12 / 3$ & $03: 00$ & - & - & - & - & - & - & 232 \\
$\mathrm{Z} 1-5$ & $12 / 4$ & $01: 04$ & 530 & 14 & 180 & 4 & 93 & 1 & - \\
$\mathrm{Z} 2-5$ & $12 / 4$ & $03: 00$ & - & - & - & - & - & - & 136 \\
$\mathrm{Z} 1-6$ & $12 / 5$ & $02: 00$ & 86 & 8 & 21 & 53 & 75 & 2 & - \\
$\mathrm{Z} 2-6$ & $12 / 5$ & $02: 00$ & - & - & - & - & - & - & 114 \\
$\mathrm{Z} 1-7$ & $12 / 8$ & $09: 10$ & 187 & 2 & 16 & 72 & 86 & 2 & - \\
$\mathrm{Z} 2-7$ & $12 / 8$ & $08: 40$ & - & - & - & - & - & - & 191 \\
$\mathrm{Z} 1-8$ & $12 / 9$ & $09: 20$ & 12 & 8 & 67 & 12 & 33 & 2 & - \\
$\mathrm{Z} 2-8$ & $12 / 9$ & $08: 30$ & - & - & - & - & - & - & 250 \\
\hline
\end{tabular}

a Samples are collected at two altitudes: $\mathrm{Z} 1$ is $2 \mathrm{~m}$ above ground, and $\mathrm{Z} 2$ is $280 \mathrm{~m}$ above ground. ${ }^{\mathrm{b}}$ Sampling duration ranges from $30 \mathrm{~s}$ to less than $5 \mathrm{~min}$, depending on the PM pollution. ${ }^{\mathrm{c}} \mathrm{MLH}$ represents the mixed-layer height, and the data are 15 min averages; MLH is less than $280 \mathrm{~m}$, and the samples collected at Z2 represent samples above the mixed layer. ${ }^{\mathrm{d}}$ If $\mathrm{PM}_{2.5}$ mass concentration is less than $75 \mu \mathrm{g} \mathrm{m}^{-3}$, samples are classified as non-haze samples, and if $\mathrm{PM}_{2.5}$ mass concentration is more than $75 \mu \mathrm{g} \mathrm{m}{ }^{-3}$, samples are classified as haze samples.

Table 2. Classification and characteristics of individual particle types.

\begin{tabular}{|c|c|c|c|}
\hline Particle type & Elemental composition & Morphology & Possible sources \\
\hline Soot particles & $\begin{array}{l}\mathrm{C} \text { and minor } \\
\text { amounts of } \mathrm{O} \text { and } \mathrm{Si}\end{array}$ & $\begin{array}{l}\text { Chain-like or compact } \\
\text { C-dominated aggregates }\end{array}$ & $\begin{array}{l}\text { Incomplete combustion of } \\
\text { biomass and fossil fuel }\end{array}$ \\
\hline $\begin{array}{l}\text { Primary organic } \\
\text { particles }\end{array}$ & $\begin{array}{l}\mathrm{C} \text { and } \mathrm{O} \text { with minor } \\
\text { amounts of } \mathrm{Si}, \mathrm{K}, \mathrm{S} \text {, and } \mathrm{Cl} \text {. }\end{array}$ & $\begin{array}{l}\text { Spherical, near-spherical, } \\
\text { or irregular shapes }\end{array}$ & $\begin{array}{l}\text { Mainly from combustion process } \\
\text { of biomass and fossil fuels }\end{array}$ \\
\hline Mineral particles & $\begin{array}{l}\mathrm{O}, \mathrm{Si}, \mathrm{Al}, \mathrm{Ca}, \mathrm{Fe} \\
\mathrm{Na}, \mathrm{K}, \mathrm{Mg}, \mathrm{Ti} \text {, and } \mathrm{S}\end{array}$ & Irregular shapes & $\begin{array}{l}\text { Re-suspended from soil dust, } \\
\text { road dust, and construction dust }\end{array}$ \\
\hline Metal particles & $\mathrm{Fe}, \mathrm{Zn}, \mathrm{Mn}, \mathrm{Ti}$, and $\mathrm{Pb}$ & $\begin{array}{l}\text { Spherical or irregular } \\
\text { shapes }\end{array}$ & $\begin{array}{l}\text { Industries, coal-fired power } \\
\text { plants, and oil refineries }\end{array}$ \\
\hline S-rich particles & $\begin{array}{l}\mathrm{S} \text { and } \mathrm{O} \text { with minor } \\
\text { amounts of } \mathrm{N} \text { and } \mathrm{K}\end{array}$ & $\begin{array}{l}\text { Spherical, near-spherical, } \\
\text { or irregular shapes }\end{array}$ & Secondary aerosol formation \\
\hline $\begin{array}{l}\text { Organic mixed with } \\
\text { sulfur-rich particles }\end{array}$ & $\begin{array}{l}\mathrm{C}, \mathrm{O} \text {, and } \mathrm{S} \text { with minor } \\
\text { amounts of } \mathrm{N}, \mathrm{K}, \text { or } \mathrm{Cl}\end{array}$ & Irregular shapes & Secondary aerosol reaction \\
\hline Other mixed particles & $\begin{array}{l}\text { Complex elemental } \\
\text { composition }\end{array}$ & $\begin{array}{l}\text { Irregular shapes with } \\
\text { different particle types }\end{array}$ & Secondary aerosol reaction \\
\hline
\end{tabular}

Soot particles, stable under the electron beam, show chainlike or compact morphologies in the atmosphere (Sorensen, 2001; Adachi et al., 2007; China et al., 2013, 2015; Bhandari et al., 2019a). Soot particles are mainly from incomplete combustion of biomass and fossil fuel.

Metal particles (Fig. 2g and h) and mineral particles (Fig. 2i) are stable under the beam irradiation. Mineral particles are mostly irregularly shaped and contain crustal ele- ments (e.g., $\mathrm{Si}, \mathrm{Al}, \mathrm{Ca}, \mathrm{Fe}, \mathrm{Na}, \mathrm{K}, \mathrm{Mg}$, Ti, and $\mathrm{S}$ ) in addition to $\mathrm{O}$. They can be generated from windblown soil dust or road dust. Metal particles are spherical or near-spherical and are mainly composed of $\mathrm{Fe}, \mathrm{Zn}, \mathrm{Mn}, \mathrm{Ti}$, and $\mathrm{Pb}$. Metal particles mainly originate from industries, coal-fired power plants, and oil refineries (Xu et al., 2019) or vehicle brakes (Hou et al., 2018). 


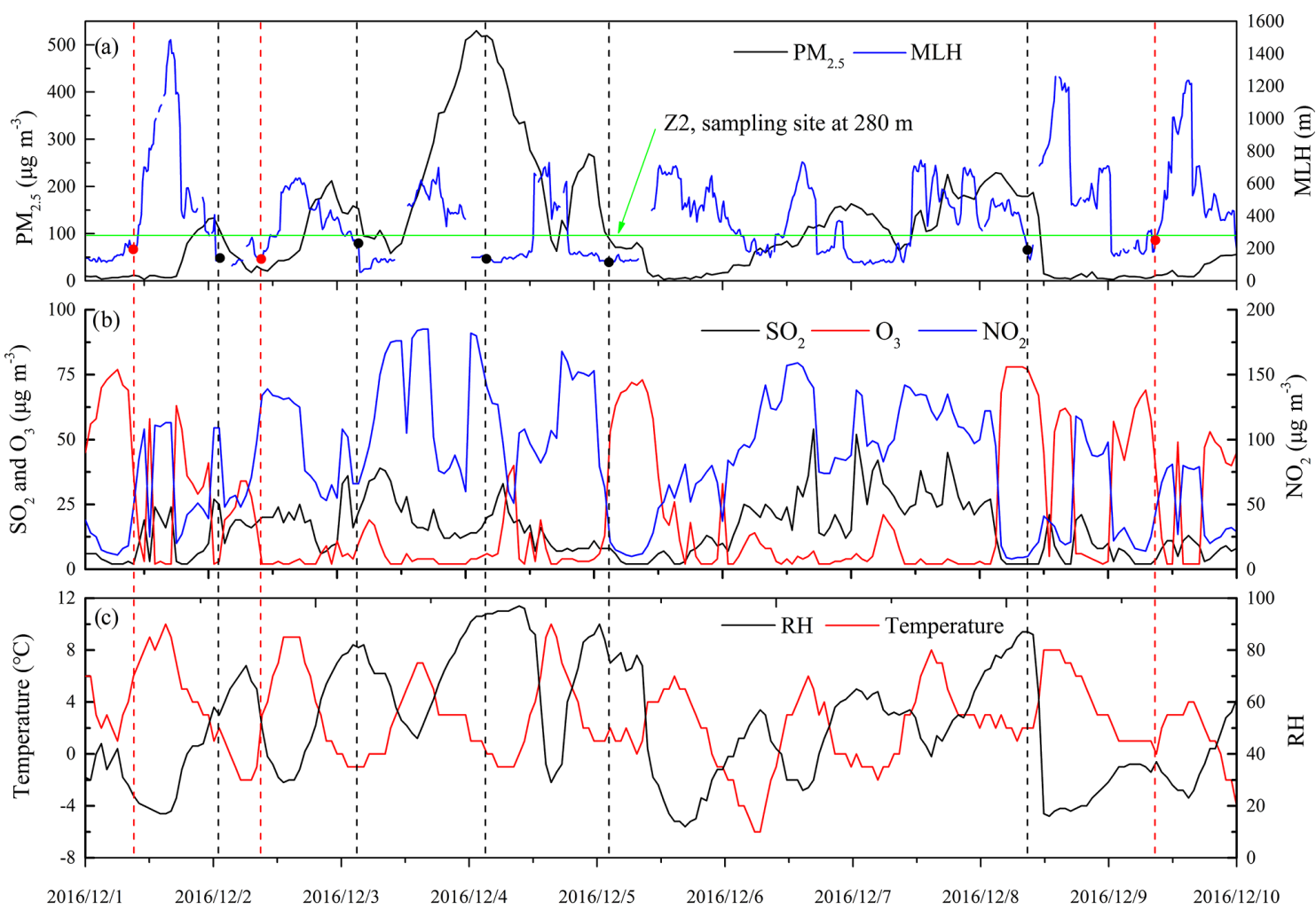

Date

Figure 1. The dashed lines represent the individual-particle sampling times, with red lines representing non-haze samples and black lines haze samples. (a) Temporal variations in mixed-layer height (MLH) and $\mathrm{PM}_{2.5}$ mass concentrations. The solid dots represent the MLH during the sampling times. (b) Temporal variations in $\mathrm{SO}_{2}, \mathrm{NO}_{2}$, and $\mathrm{O}_{3}$ at ground level at the Olympic Park monitor site, which is the closest national air quality monitor station to the sampling site $(\sim 1.5 \mathrm{~km})$. (c) Temporal variations in temperature $(T)$ and relative humidity (RH) at ground level. The date was obtained from the Ministry of Ecology and Environment of China (https://www.aqistudy.cn, last access: 31 March 2021).

Internally mixed particles (Fig. $2 \mathrm{j}-\mathrm{p}$ ) are particles with at least two of the above components. They usually show relatively larger diameter. We further classify them as internally mixed organic and sulfur-rich particles (OP-S) (Fig. 2j-1) and other mixed particles (Fig. $2 \mathrm{~m}-\mathrm{p}$ ).

\subsection{Comparison of haze and non-haze individual particles at ground level}

Haze periods are defined as hourly average $\mathrm{PM}_{2.5}$ mass concentration greater than $75 \mathrm{\mu g} \mathrm{m}^{-3}$ during collection time; the rest are defined as non-haze periods. A total of 1538 individual particles among eight samples at ground level were analyzed based on the TEM results. The relative number percentage (N(type i) / N(total) 100) of particles in each sample was calculated. The results are provided in Table 3 and shown in Fig. 3. During non-haze periods, the particles were composed of mineral particles (42.5\%), POA particles $(21.1 \%)$, S-rich particles $(20.0 \%)$, soot particles $(6.4 \%)$, other mixed particles $(5.6 \%)$, metal particles $(2.83 \%)$, and OP-S (1.6\%) in descending order. During haze periods, the particles were composed of POA particles (28.3\%), S-rich particles $(23.5 \%)$, mineral particles $(18.1 \%)$, OP-S $(13.1 \%)$, other mixed particles $(8.8 \%)$, soot particles $(6.6 \%)$, and metal particles $(1.7 \%)$ in descending order.

The mineral particles are mainly from re-suspended road dust, soil dust, and construction dust during non-desert transport dust episodes (Sun et al., 2006; Gao et al., 2016; Wang et al., 2017). The relative number percentage of mineral particles was much higher during non-haze periods $(42.5 \%)$ than during haze periods (18.1\%), as shown in Fig. 3.

However, the content of mixed particles including OP-S and other mixed particles during haze periods $(21.9 \%)$ was much higher than during non-haze periods $(7.2 \%)$, suggesting that there was more secondary aerosol formation during haze periods. High secondary aerosol formation in winter in Beijing during the pollution periods was also found in previous studies (Huang et al., 2014; Sun et al., 2016; Li et al., 2017a). Secondary aerosol formation was expected since the $\mathrm{RH}$ during the haze periods was relatively higher than during non-haze periods, as shown in Table 1 and Fig. 1, which facilitated chemical reactions of gaseous pollutants (Liu et al., 

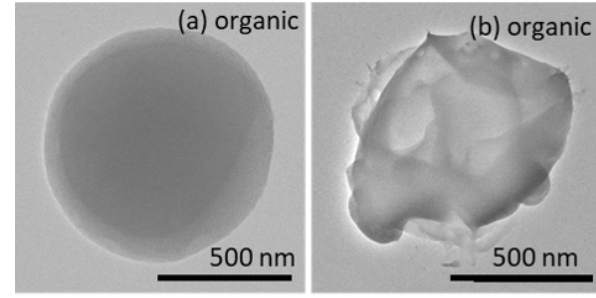

(e) soot
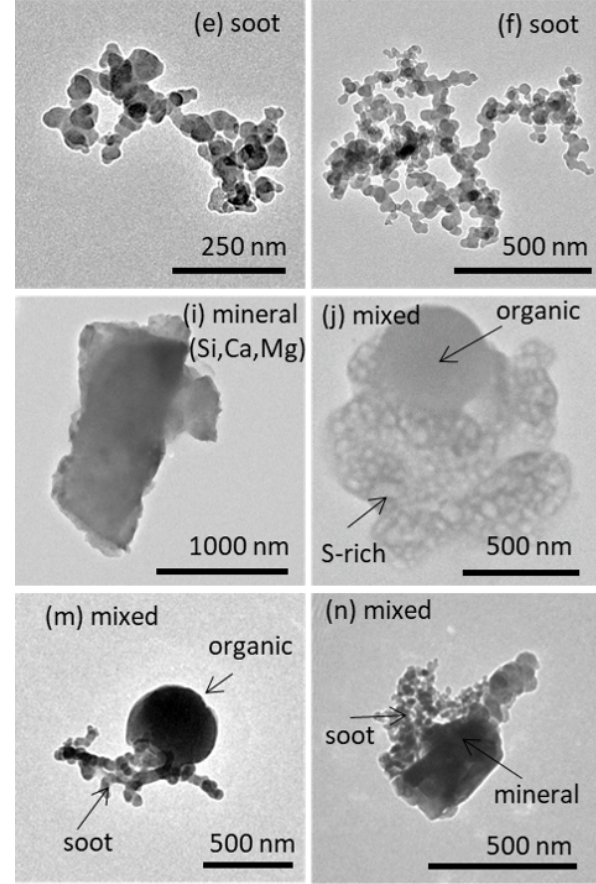

(n) mixed
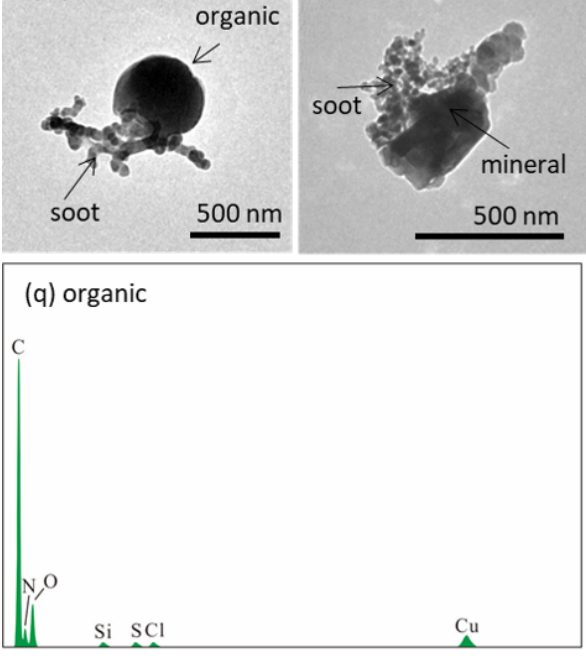

Energy (KeV)

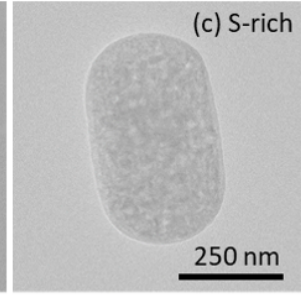

(g) metal (Ti)
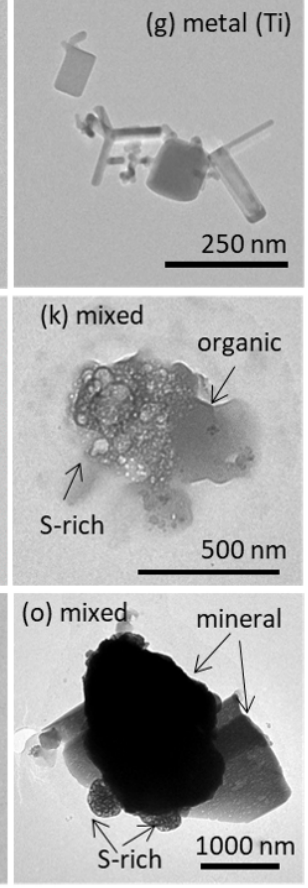

(r) mineral (Si, Ca, Mg)

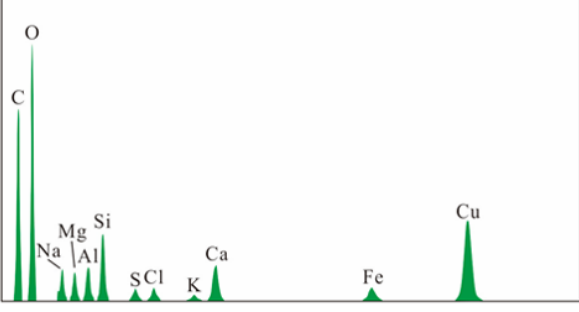

Energy (KeV)
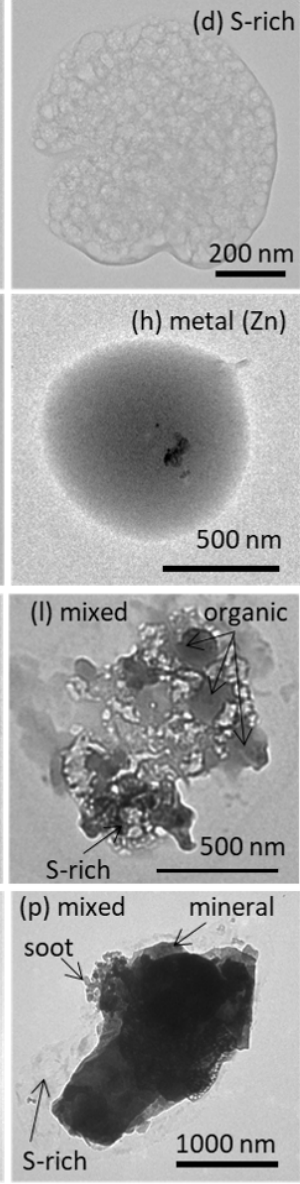

(1)

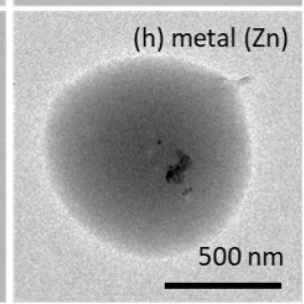

Figure 2. Examples of morphologies and mixing characteristics of individual aerosol particles in winter in Beijing at ground level and above the mixed layer. (a) Spherical organic particle, (b) irregularly shaped organic particle, (c-d) S-rich particles, (e-f) soot particles, (g-h) metal particles, (i) mineral particles, (j-l) OP-S mixed particles, and (m-p) other mixed-particle types. Panels (q) and (r) are EDS of (b) and (i). The difference between the particles in (b) and (i) is that organic particles (b) are mainly composed of $\mathrm{C}$ and $\mathrm{O}$, while minerals (i) are mainly composed of $\mathrm{O}, \mathrm{Si}, \mathrm{Ca}$, and $\mathrm{Mg}$.

2016; Wang et al., 2016). Also, the average content of POA particles and S-rich particles was higher during haze periods than during non-haze periods.

\subsection{Comparison of individual particles at ground level and above the MLH}

A total of 1519 individual particles among eight samples above the MLH were analyzed. The results are provided in Table 3 and shown in Fig. 3. We found that the relative number percentage of mineral particles at ground level was larger than that above the MLH. For example, mineral particles at 


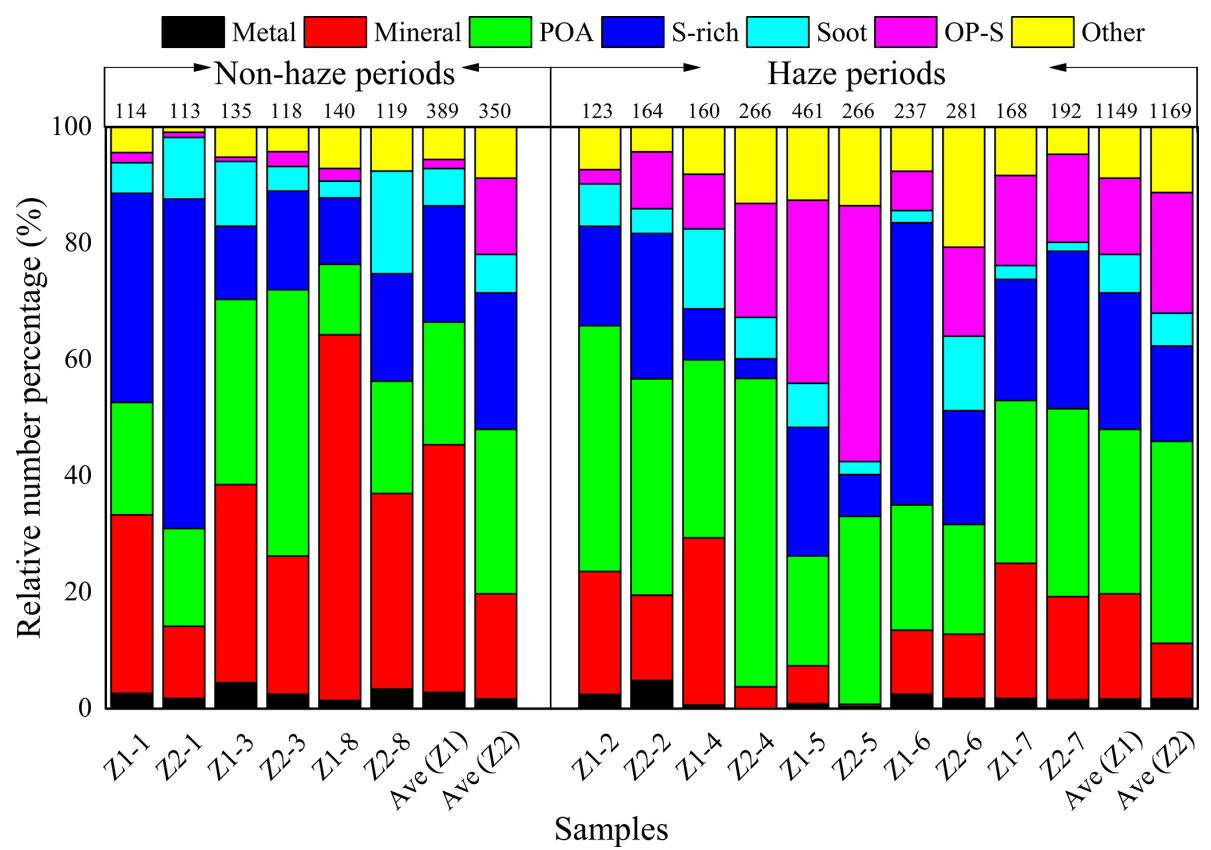

Figure 3. Relative number percentage of different particle types at ground level (Z1) and above the mixed-layer height (Z2). The number above each bar represents the total particle number analyzed in each sample.

Table 3. Relative number percentage of individual particles.

\begin{tabular}{|c|c|c|c|c|c|c|c|c|c|}
\hline Air qualities & Sample ID & Number & Metals & Minerals & POAs & S-rich & Soot & $\mathrm{OP}-\mathrm{S}$ & Other \\
\hline \multirow{8}{*}{$\begin{array}{l}\text { Non-haze } \\
\text { periods }\end{array}$} & $\mathrm{Z} 1-1$ & 114 & 2.6 & 30.7 & 19.3 & 36.0 & 5.3 & 1.8 & 4.4 \\
\hline & Z2-1 & 113 & 1.8 & 12.4 & 16.8 & 56.6 & 10.6 & 0.9 & 0.9 \\
\hline & $\mathrm{Z} 1-3$ & 135 & 4.4 & 34.1 & 31.9 & 12.6 & 11.1 & 0.7 & 5.2 \\
\hline & $\mathrm{Z} 2-3$ & 118 & 2.5 & 23.7 & 45.8 & 17.0 & 4.2 & 2.5 & 4.2 \\
\hline & $\mathrm{Z} 1-8$ & 140 & 1.4 & 62.9 & 12.1 & 11.4 & 2.9 & 2.1 & 7.1 \\
\hline & $\mathrm{Z} 2-8$ & 119 & 3.4 & 33.6 & 19.3 & 18.5 & 17.7 & 0.0 & 7.6 \\
\hline & Ave (Z1) & 389 & 2.8 & 42.5 & 21.1 & 20.0 & 6.4 & 1.6 & 5.6 \\
\hline & Ave (Z2) & 350 & 2.6 & 23.2 & 27.3 & 30.7 & 10.8 & 1.1 & 4.2 \\
\hline \multirow{12}{*}{$\begin{array}{l}\text { Haze } \\
\text { periods }\end{array}$} & $\mathrm{Z} 1-2$ & 123 & 2.4 & 21.1 & 42.3 & 17.1 & 7.3 & 2.4 & 7.3 \\
\hline & $\mathrm{Z} 2-2$ & 164 & 4.9 & 14.6 & 37.2 & 25.0 & 4.3 & 9.8 & 4.3 \\
\hline & $\mathrm{Z} 1-4$ & 160 & 0.6 & 28.8 & 30.6 & 8.8 & 13.8 & 9.4 & 8.1 \\
\hline & $\mathrm{Z} 2-4$ & 266 & 0.0 & 3.8 & 53.0 & 3.4 & 7.1 & 19.6 & 13.2 \\
\hline & $\mathrm{Z} 1-5$ & 461 & 0.9 & 6.5 & 18.9 & 22.1 & 7.6 & 31.5 & 12.6 \\
\hline & Z2-5 & 266 & 0.4 & 0.4 & 32.3 & 7.1 & 2.3 & 44.0 & 13.5 \\
\hline & Z1-6 & 237 & 2.5 & 11.0 & 21.5 & 48.5 & 2.1 & 6.8 & 7.6 \\
\hline & Z2-6 & 281 & 1.8 & 11.0 & 18.9 & 19.6 & 12.8 & 15.3 & 20.6 \\
\hline & $\mathrm{Z} 1-7$ & 168 & 1.8 & 23.2 & 28.0 & 20.8 & 2.4 & 15.5 & 8.3 \\
\hline & $\mathrm{Z} 2-7$ & 192 & 1.6 & 17.7 & 32.3 & 27.1 & 1.6 & 15.1 & 4.7 \\
\hline & Ave (Z1) & 1149 & 1.7 & 18.1 & 28.3 & 23.5 & 6.6 & 13.1 & 8.8 \\
\hline & Ave (Z2) & 1169 & 1.7 & 9.5 & 34.7 & 16.4 & 5.6 & 20.7 & 11.3 \\
\hline
\end{tabular}

ground level and above the MLH during non-haze periods accounted for $42.5 \%$ and $23.2 \%$, respectively, and during haze periods the values are $18.1 \%$ and $9.5 \%$, respectively. Srich particles during non-haze periods accounted for $20.0 \%$ at ground level, less than the value of $30.7 \%$ above the MLH. However, not all the samples above the MLH during haze periods showed higher relative number percentage of S-rich particles than at ground level. This might be because some of the S-rich particles above the MLH were mixed with other particles, forming mixed particles. Another reason might be that the higher relative number percentage of mixed particles diluted the relative number percentage of S-rich parti- 


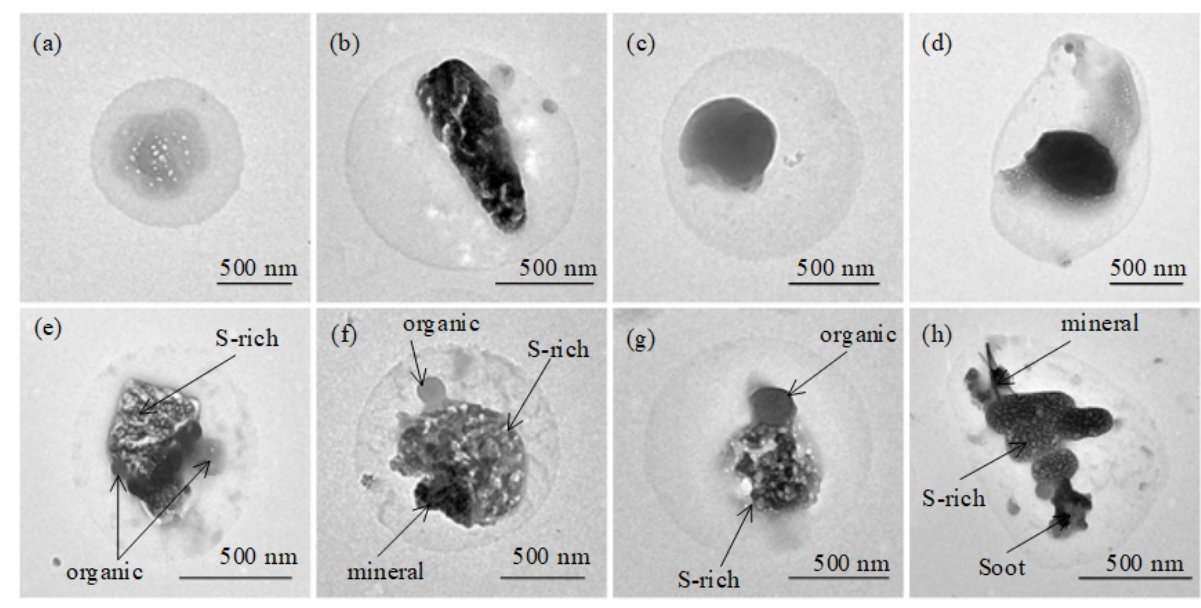

Figure 4. Images of core-shell-structured particles. (a-b) S-rich cores, (c-d) organic cores, and (e-h) mixed cores.

cles. The mixed particles during haze periods accounted for $32.0 \%$ above the MLH, higher than that of $21.9 \%$ at ground level. We also found that POA particles above the MLH accounted for higher relative number percentage than at ground level, although there was some variance. For example, samples 4 and 6 showed a higher relative number percentage of POA particles at ground level. That might be because some of the POA particles were mixed with S-rich particles, and OP-S showed a higher relative number percentage above the MLH than at ground level in samples 4 and 6. Metals and soot only accounted for a few relative number percentages in all samples, and they did not show much difference at ground level and above the MLH. Particles above the MLH were transported either from the surrounding areas or from ground sources. In both cases, they were subject to atmospheric processes, leading to their aging.

\subsection{Aging of particles}

In the atmosphere, particles are subjected to the aging process. During the aging process of aerosol particles, secondary species can coat pre-existing particles ( $\mathrm{Li}$ and Shao, 2009; Laskin et al., 2016; Li et al., 2016b; Niu et al., 2016; Tang et al., 2016; Chen et al., 2017; Hou et al., 2018; Unga et al., 2018; Xu et al., 2019). Using high-resolution TEM images, it is possible to identify the core-shell structure of particles (Li et al., 2016a). For example, Fig. 4a and b showed $\mathrm{S}$-rich particles coated by secondary species. Figure $4 \mathrm{c}$ and $\mathrm{d}$ were POA particles coated with secondary species. Figure $4 \mathrm{e}-\mathrm{h}$ showed core-shell-structured particles with some mixed-particle cores. In this study, we found that the coreshell-structured particles accounted for $20 \%$ during haze periods, with $17 \%$ at ground level and $23 \%$ above the MLH, but only $2 \%$ during non-haze periods. These results demonstrated a general trend that the core-shell-structured particles during haze periods were much higher than during non-haze periods. Also, the average $D_{\text {Aeq }}$ of particles was larger dur-

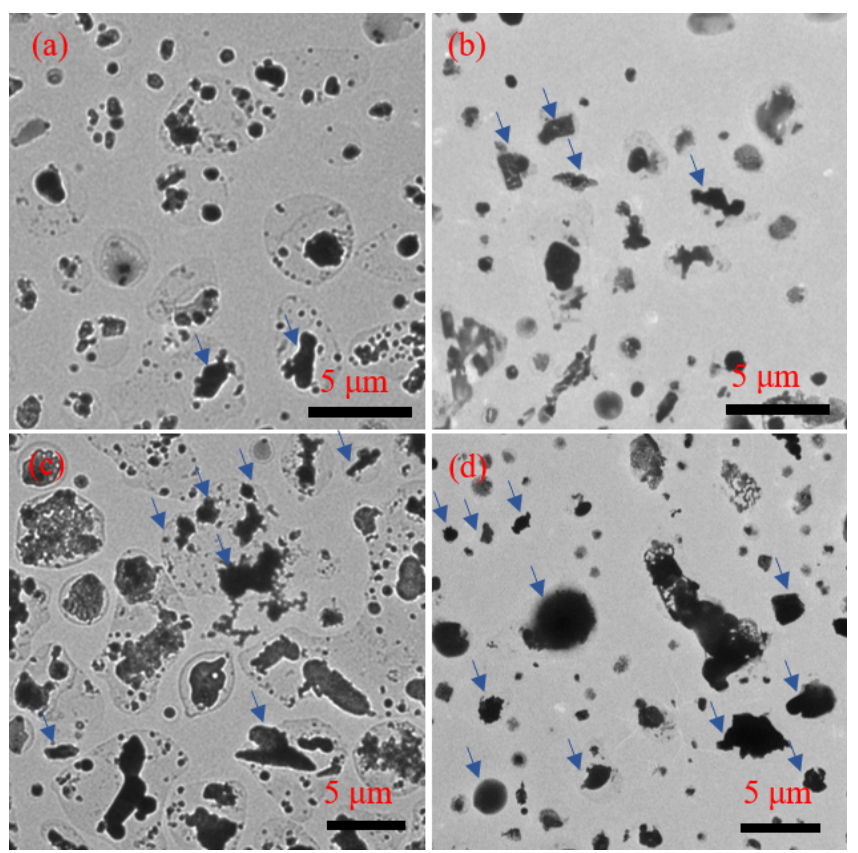

Figure 5. Low-magnification images of individual particles. Panels (a) and (c) are particles above the mixed-layer height (MLH) at different size ranges. Panels (b) and (d) are particles at ground level at different size ranges. More coated particles were found above the MLH. Arrows show part of the mineral particles.

ing haze periods than during non-haze periods, as shown in Fig. S3. These results confirmed that particles during haze periods underwent more extensive aging than during nonhaze periods.

The coating of atmospheric particles is often caused by aging mechanisms such as coagulation, condensation, and heterogeneous chemical reactions (Kahnert, 2015; Müller et al., 2017, Zhang et at., 2012). Figure 5 shows low-magnification images of particles at ground level and above the MLH. 


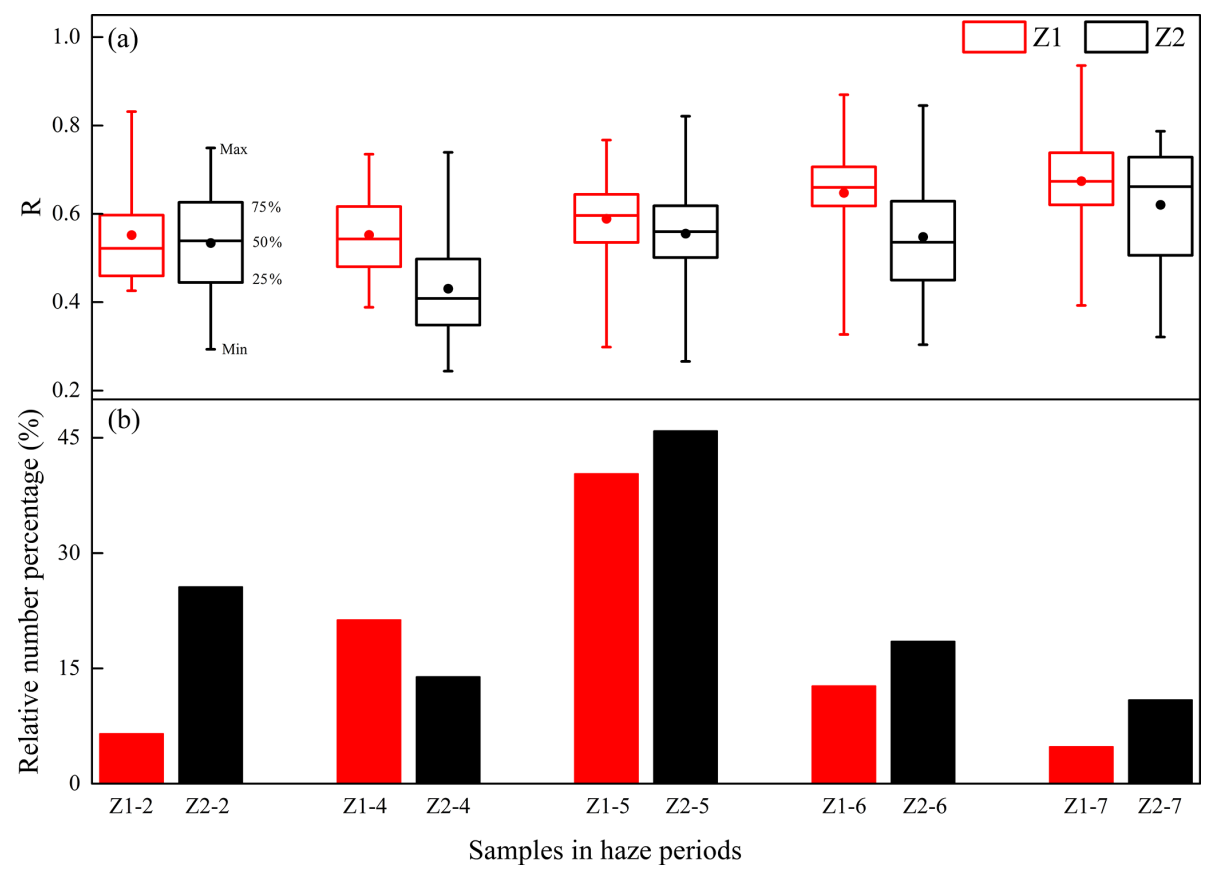

Figure 6. (a) $R$ is the $\mathrm{C} / \mathrm{S}$ ratio ( $D_{\text {Aeq }}$ ratio of the core to the whole particle including the shell) of particles during haze periods at ground level (Z1) and above the mixed-layer height (Z2); solid dots represent the average value and (b) the corresponding relative number percentage of core-shell-structured particles.

More core-shell particles were found above the MLH. The core / shell ratio $(R)$, which is the ratio of the $D_{\text {Aeq }}$ of the core to the $D_{\text {Aeq }}$ of the whole particle including the coating, has been used to evaluate the aging process of aerosol particles in different studies (Niu et al., 2012, 2016; Hou et al., 2018). The value of $R$ ranged from 0 to less than 1 . A smaller $R$ value means the particles are more coated and thus are subjected to a more extensive degree of aging (Hou et al., 2018). Because a high number percentage of core-shell-structured particles were only found during haze periods, we only measured $R$ of core-shell-structured particles during the haze periods (including the samples 2, 4, 5, 6, and 7). Figure 6a shows the $R$ value of each sample during the haze periods. We can see from Fig. 6a that all the samples showed a smaller average $R$ value above the MLH compared with those from the ground level. The average $R$ value above the MLH $(0.54)$ was smaller than at ground level (0.59). Additionally, the relative number percentage of core-shell-structured particles was higher above the MLH than at ground level, except for sample 4 . These findings indicated that the particles above the MLH were more aged than those at ground level.

Figure $\mathrm{S} 3$ shows the total particle number size distribution; the relative number percentage of the larger-sized particles clearly increased when considering the coatings compared to only considering the core size during haze periods. The change in optical properties due to coating was calculated in various studies by using different methods (Cappa et al., 2012; Scarnato et al., 2013; Liu et al., 2015; Saliba et al.,
2016; Unga et al., 2018). When host particles were coated, their optical properties might be amplified (Khalizov et al., 2009; Peng et al., 2016). Also, organic coating can influence the hygroscopic properties and the viscosity of mixed particles (Sharma et al., 2018; Unga et al., 2018) and thus can influence cloud formation activity (Kerminen et al., 2012).

\subsection{Possible sources of organic particles}

Our results showed a higher relative number percentage of POA particles both during non-haze $(21.1 \%)$ and haze periods $(28.3 \%)$ in winter in Beijing, compared with a tunnel environment $(\sim 5 \%)$, where the vehicle emissions were the main pollution sources (Hou et al., 2018). Also, recent studies did not find abundant POA particles in North China during spring and summer (Yuan et al., 2015; Li et al., 2016b; $\mathrm{Xu}$ et al., 2019). Instead, a larger number percentage of POA particles has been found in winter using electron microscopy in previous studies, including an outflow of a haze plume in East Asia (Zhu et al., 2013), a coal-burning region in China's Loess Plateau (Li et al., 2012), three sampling sites in the North China Plain (Chen et al., 2017), and urban and rural sites in Northeast China (Xu et al., 2017; Zhang et al., 2017). These results suggested that POA particles accounted for a large number percentage of the particles in North China in winter.

Most of the POA particles in our study were spherical or nearly spherical in shape according to the projected images, and they were stable under strong electron beam irradiation 


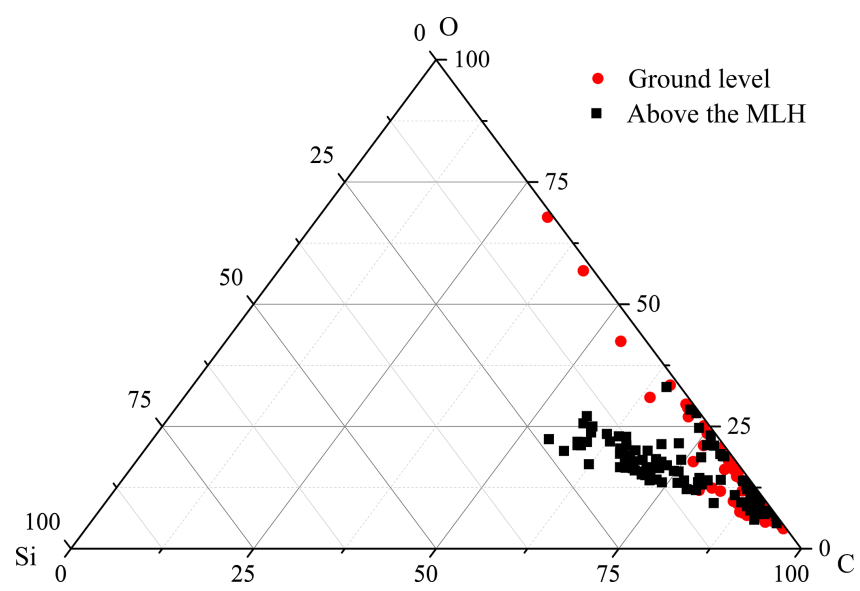

Figure 7. Triangular diagram showing the weight ratio of $\mathrm{C}-\mathrm{O}-\mathrm{Si}$ of primary organic aerosols (POAs) at ground level and above the mixed-layer height $(\mathrm{MLH})$.

and appear as dark features in TEM images, which reflected their high thickness and refractory properties (Ebert et al., 2016), suggesting that they were formed through the cooling process after the biomass- or fossil-fuel-combustion pyrolysis products of volatile organic compounds were emitted into the atmosphere (Wang et al., 2015; Chen et al., 2017; Zhang et al., 2017).

These spherical or near-spherical POA particles are considered to be brown carbon (Zhang et al., 2020). Brown carbon plays a significant role in atmospheric shortwave absorption and can cause warming of the atmosphere (Adachi and Buseck, 2011; Hoffer et al., 2016). Some researchers have found that the primary POA particles from coal combustion have more $\mathrm{Si}$ than those from biomass burning ( $\mathrm{Li}$ et al., 2012; Chen et al., 2017). The weight ratio of $\mathrm{C}-\mathrm{O}-$ $\mathrm{Si}$ at ground level and above the MLH is shown in Fig. 7. More coal-burning-related POA particles were found above the MLH. Since the relative number percentage of POA particles affected by coal burning is higher above the MLH than at ground level, POA particles above the MLH are not all from ground level and might originate from surrounding areas influenced by coal combustion. The results were supported by the $24 \mathrm{~h}$ backward trajectories, which showed that air masses above the MLH during haze periods were from the northern and western direction of Beijing, as shown in Fig. S4. It is reasonable that Beijing has implemented strict air pollution control measures, including using natural gas to replace domestic coal burning. The particles above the MLH can contribute to Beijing air pollution by mixing down to the ground.

\section{Conclusions}

Detailed morphologies and elemental compositions of individual aerosol particles at ground level and above the mixed- layer height were analyzed in this study. The following conclusions were reached:

1. Particles were classified into primary organic particles, S-rich particles, mineral particles, metal particles, soot, internally mixed organic and sulfur-rich particles, and other mixed particles. Compared with non-haze periods, haze periods were associated with a relatively lower number percentage of mineral particles and a relatively higher number percentage of mixed particles.

2. Compared with the aerosol samples at ground level, the samples above the MLH had a lower relative number percentage of mineral particles, a higher number percentage of coated particles, and a smaller core/shell ratio of coated particles. More coated particles and a higher core/shell ratio in the aerosol samples above the mixed layer suggested that the particles above the mixed layer were more aged.

3. The relative number percentage of primary organic particles accounted for $21.1 \%$ during non-haze periods and $28.3 \%$ during haze periods in winter in Beijing. More primary organic particles above the mixed layer were associated with coal combustion according to the $\mathrm{C}-\mathrm{O}-$ $\mathrm{Si}$ ratio, and the long-range transportation of air masses from surrounding areas has an important influence for Beijing air.

Data availability. Data used in this study are available from the corresponding author upon request (ShaoL@cumtb.edu.cn).

Supplement. The supplement related to this article is available online at: https://doi.org/10.5194/acp-21-5301-2021-supplement.

Author contributions. WW, LS, CM, JX, and ZS conceived the manuscript. WW, YL, XF, and MZ conducted the sample collection and analysis. SK and SG conducted the MLH measurement. $\mathrm{CM}$ and JB conducted manuscript modification.

Competing interests. The authors declare that they have no conflict of interest.

Acknowledgements. We thank Zifa Wang and Pingqing Fu at the IAP for supporting sample collection.
Financial support. This research has been supported by the National Natural Science Foundation of China (grant nos. 42075107 and 42065007); the International Cooperation Projects of the National Natural Science Foundation of China (grant no. 41571130031); the China Scholarship Council (grant no. 
201806430015); the Yue Qi Scholar Fund of the China University of Mining and Technology (Beijing); the US Department of Energy (DOE), Office of Biological and Environmental Research (OBER), Atmospheric System Research (grant nos. DE-SC0011935 and DESC0018931); and the Natural Environmental Research Council (grant no. NE/N007190/1).

Review statement. This paper was edited by John Liggio and reviewed by Weijun Li and one anonymous referee.

\section{References}

Adachi, K. and Buseck, P. R.: Atmospheric tar balls from biomass burning in Mexico, J. Geophys. Res.-Atmos., 116, D05204, https://doi.org/10.1029/2010jd015102, 2011

Adachi, K., Chung, S. H., Friedrich, H., and Buseck, P. R.: Fractal parameters of individual soot particles determined using electron tomography: Implications for optical properties, J. Geophys. Res., 112, D14202, https://doi.org/10.1029/2006jd008296, 2007.

Bhandari, J., China, S., Onasch, T., Wolff, L., Lambe, A., Davidovits, P., Cross, E., Ahern, A., Olfert, J., Dubey, M., and Mazzoleni, C.: Effect of Thermodenuding on the Structure of Nascent Flame Soot Aggregates, Atmosphere, 8, 166, https://doi.org/10.3390/atmos8090166, 2017.

Bhandari, J., China, S., Chandrakar, K. K., Kinney, G., Cantrell, W., Shaw, R. A., Mazzoleni, L. R., Girotto, G., Sharma, N., Gorkowski, K., Gilardoni, S., Decesari, S., Facchini, M. C., Zanca, N., Pavese, G., Esposito, F., Dubey, M. K., Aiken, A. C., Chakrabarty, R. K., Moosmuller, H., Onasch, T. B., Zaveri, R. A., Scarnato, B. V., Fialho, P., and Mazzoleni, C.: Extensive Soot Compaction by Cloud Processing from Laboratory and Field Observations, Sci. Rep., 9, 11824, https://doi.org/10.1038/s41598019-48143-y, 2019a.

Bhandari, J., China, S., Girotto, G., Scarnato, B. V., Gorkowski, K., Aiken, A. C., Dubey, M. K., and Mazzoleni, C.: Optical properties and radiative forcing of fractal-like tar ball aggregates from biomass burning, J. Quant. Spectrosc. Ra., 230, 65-74, https://doi.org/10.1016/j.jqsrt.2019.01.032, 2019b.

Bond, T. C. and Bergstrom, R. W.: Light Absorption by Carbonaceous Particles: An Investigative Review, Aerosol. Sci. Tech., 40, 27-67, https://doi.org/10.1080/02786820500421521, 2006.

Brock, C. A., Wagner, N. L., Anderson, B. E., Attwood, A. R., Beyersdorf, A., Campuzano-Jost, P., Carlton, A. G., Day, D. A., Diskin, G. S., Gordon, T. D., Jimenez, J. L., Lack, D. A., Liao, J., Markovic, M. Z., Middlebrook, A. M., Ng, N. L., Perring, A. E., Richardson, M. S., Schwarz, J. P., Washenfelder, R. A., Welti, A., Xu, L., Ziemba, L. D., and Murphy, D. M.: Aerosol optical properties in the southeastern United States in summer - Part 1: Hygroscopic growth, Atmos. Chem. Phys., 16, 49875007, https://doi.org/10.5194/acp-16-4987-2016, 2016.

Buseck, P. R., Adachi, K., Gelencsér, A., Tompa, É., and Pósfai, M.: Ns-Soot: A Material-Based Term for Strongly LightAbsorbing Carbonaceous Particles, Aerosol. Sci. Tech., 48, 777788, https://doi.org/10.1080/02786826.2014.919374, 2014.

Cappa, C. D., Onasch, T. B., Massoli, P., Worsnop, D. R., Bates, T. S., Cross, E. S., Davidovits, P., Hakala, J., Hayden, K. L., Jobson, B. T., Kolesar, K. R., Lack, D. A., Lerner, B. M., Li, S.-M., Mellon, D., Nuaaman, I., Olfert, J. S., Petäjä, T., Quinn,
P. K., Song, C., Subramanian, R., Williams, E. J., and Zaveri, R. A.: Radiative Absorption Enhancements Due to the Mixing State of Atmospheric Black Carbon, Science, 337, 1078, https://doi.org/10.1126/science.1223447, 2012.

Carnerero, C., Pérez, N., Reche, C., Ealo, M., Titos, G., Lee, H.K., Eun, H.-R., Park, Y.-H., Dada, L., Paasonen, P., Kerminen, V.-M., Mantilla, E., Escudero, M., Gómez-Moreno, F. J., Alonso-Blanco, E., Coz, E., Saiz-Lopez, A., Temime-Roussel, B., Marchand, N., Beddows, D. C. S., Harrison, R. M., Petäjä, T., Kulmala, M., Ahn, K.-H., Alastuey, A., and Querol, X.: Vertical and horizontal distribution of regional new particle formation events in Madrid, Atmos. Chem. Phys., 18, 16601-16618, https://doi.org/10.5194/acp-18-16601-2018, 2018.

Chen, S., Xu, L., Zhang, Y., Chen, B., Wang, X., Zhang, X., Zheng, M., Chen, J., Wang, W., Sun, Y., Fu, P., Wang, Z., and Li, W.: Direct observations of organic aerosols in common wintertime hazes in North China: insights into direct emissions from Chinese residential stoves, Atmos. Chem. Phys., 17, 1259-1270, https://doi.org/10.5194/acp-17-1259-2017, 2017.

Chen, Y., Ebenstein, A., Greenstone, M., and Li, H.: Evidence on the impact of sustained exposure to air pollution on life expectancy from China's Huai River policy, P. Natl. Acad Sci. USA, 110, 12936-12941, https://doi.org/10.1073/pnas.1300018110, 2013.

China, S., Mazzoleni, C., Gorkowski, K., Aiken, A. C., and Dubey, M. K.: Morphology and mixing state of individual freshly emitted wildfire carbonaceous particles, Nat. Commun., 4, 2122, https://doi.org/10.1038/ncomms3122, 2013.

China, S., Scarnato, B., Owen, R. C., Zhang, B., Ampadu, M. T., Kumar, S., Dzepina, K., Dziobak, M. P., Fialho, P., Perlinger, J. A., Hueber, J., Helmig, D., Mazzoleni, L. R., and Mazzoleni, C.: Morphology and mixing state of aged soot particles at a remote marine free troposphere site: Implications for optical properties, Geophys. Res. Lett., 42, 1243-1250, https://doi.org/10.1002/2014gl062404, 2015.

De Marco, A., Proietti, C., Anav, A., Ciancarella, L., D’Elia, I., Fares, S., Fornasier, M. F., Fusaro, L., Gualtieri, M., Manes, F., Marchetto, A., Mircea, M., Paoletti, E., Piersanti, A., Rogora, M., Salvati, L., Salvatori, E., Screpanti, A., Vialetto, G., Vitale, M., and Leonardi, C.: Impacts of air pollution on human and ecosystem health, and implications for the National Emission Ceilings Directive: Insights from Italy, Environ. Int., 125, 320 333, https://doi.org/10.1016/j.envint.2019.01.064, 2019.

Ebert, M., Weigel, R., Kandler, K., Günther, G., Molleker, S., Grooß, J.-U., Vogel, B., Weinbruch, S., and Borrmann, S.: Chemical analysis of refractory stratospheric aerosol particles collected within the arctic vortex and inside polar stratospheric clouds, Atmos. Chem. Phys., 16, 8405-8421, https://doi.org/10.5194/acp-16-8405-2016, 2016.

Gao, J., Peng, X., Chen, G., Xu, J., Shi, G. L., Zhang, Y. C., and Feng, Y. C.: Insights into the chemical characterization and sources of $\mathrm{PM}_{2.5}$ in Beijing at a 1$\mathrm{h}$ time resolution, Sci. Total Environ., 542, 162-171, https://doi.org/10.1016/j.scitotenv.2015.10.082, 2016.

Guo, S., Hu, M., Zamora, M. L., Peng, J., Shang, D., Zheng, J., Du, Z., Wu, Z., Shao, M., Zeng, L., Molina, M. J., and Zhang, R.: Elucidating severe urban haze formation in China, P. Natl. Acad Sci. USA, 111, 17373-17378, https://doi.org/10.1073/pnas.1419604111, 2014. 
Heald, C. L., Jacob, D. J., Park, R. J., Alexander, B., Fairlie, T. D., Yantosca, R. M., and Chu, D. A.: Transpacific transport of Asian anthropogenic aerosols and its impact on surface air quality in the United States, J. Geophys. Res., 111, D14310, https://doi.org/10.1029/2005jd006847, 2006.

Hoffer, A., Tóth, A., Nyirő-Kósa, I., Pósfai, M., and Gelencsér, A.: Light absorption properties of laboratory-generated tar ball particles, Atmos. Chem. Phys., 16, 239-246, https://doi.org/10.5194/acp-16-239-2016, 2016.

Hou, C., Shao, L., Hu, W., Zhang, D., Zhao, C., Xing, J., Huang, X., and Hu, M.: Characteristics and aging of trafficderived particles in a highway tunnel at a coastal city in southern China, Sci. Total Environ., 619-620, 1385-1393, https://doi.org/10.1016/j.scitotenv.2017.11.165, 2018.

Huang, R. J., Zhang, Y., Bozzetti, C., Ho, K. F., Cao, J. J., Han, Y., Daellenbach, K. R., Slowik, J. G., Platt, S. M., Canonaco, F., Zotter, P., Wolf, R., Pieber, S. M., Bruns, E. A., Crippa, M., Ciarelli, G., Piazzalunga, A., Schwikowski, M., Abbaszade, G., SchnelleKreis, J., Zimmermann, R., An, Z., Szidat, S., Baltensperger, U., El Haddad, I., and Prevot, A. S.: High secondary aerosol contribution to particulate pollution during haze events in China, Nature, 514, 218-222, https://doi.org/10.1038/nature13774, 2014.

Jacobson, M. Z.: Strong radiative heating due to the mixing state of black carbon in atmospheric aerosols, Nature, 409, 695-697, https://doi.org/10.1038/35055518, 2001.

Kahnert, M.: Modelling radiometric properties of inhomogeneous mineral dust particles: Applicability and limitations of effective medium theories, J. Quant. Spectrosc. Ra., 152, 16-27, https://doi.org/10.1016/j.jqsrt.2014.10.025, 2015.

Kerminen, V.-M., Paramonov, M., Anttila, T., Riipinen, I., Fountoukis, C., Korhonen, H., Asmi, E., Laakso, L., Lihavainen, H., Swietlicki, E., Svenningsson, B., Asmi, A., Pandis, S. N., Kulmala, M., and Petäjä, T.: Cloud condensation nuclei production associated with atmospheric nucleation: a synthesis based on existing literature and new results, Atmos. Chem. Phys., 12, 1203712059, https://doi.org/10.5194/acp-12-12037-2012, 2012.

Khalizov, A. F., Xue, H., Wang, L., Zheng, J., and Zhang, R.: Enhanced Light Absorption and Scattering by Carbon Soot Aerosol Internally Mixed with Sulfuric Acid, J. Phys. Chem. A, 113, 1066-1074, https://doi.org/10.1021/jp807531n, 2009.

Kotthaus, S. and Grimmond, C. S. B.: Atmospheric boundarylayer characteristics from ceilometer measurements. Part 1: A new method to track mixed layer height and classify clouds, Q. J. Roy. Meteorol. Soc., 144, 1525-1538, https://doi.org/10.1002/qj.3299, 2018.

Kotthaus, S., O'Connor, E., Münkel, C., Charlton-Perez, C., Haeffelin, M., Gabey, A. M., and Grimmond, C. S. B.: Recommendations for processing atmospheric attenuated backscatter profiles from Vaisala CL31 ceilometers, Atmos. Meas. Tech., 9, 37693791, https://doi.org/10.5194/amt-9-3769-2016, 2016.

Laskin, A., Gilles, M. K., Knopf, D. A., Wang, B., and China, S.: Progress in the Analysis of Complex Atmospheric Particles, Annu. Rev. Anal. Chem., 9, 117-143, https://doi.org/10.1146/annurev-anchem-071015-041521, 2016.

Lelieveld, J., Evans, J. S., Fnais, M., Giannadaki, D., and Pozzer, A.: The contribution of outdoor air pollution sources to premature mortality on a global scale, Nature, 525, 367-371, https://doi.org/10.1038/nature15371, 2015.
Li, J., Du, H., Wang, Z., Sun, Y., Yang, W., Li, J., Tang, X., and Fu, P.: Rapid formation of a severe regional winter haze episode over a mega-city cluster on the North China Plain, Environ. Pollut., 223, 605-615, https://doi.org/10.1016/j.envpol.2017.01.063, 2017a.

Li, W. and Shao, L.: Transmission electron microscopy study of aerosol particles from the brown hazes in northern China, J. Geophys. Res., 114, D09302, https://doi.org/10.1029/2008jd011285, 2009.

Li, W., Shi, Z., Zhang, D., Zhang, X., Li, P., Feng, Q., Yuan, Q., and Wang, W.: Haze particles over a coal-burning region in the China Loess Plateau in winter: Three flight missions in December 2010, J. Geophys. Res.-Atmos, 117, D12306, https://doi.org/10.1029/2012jd017720, 2012.

Li, W., Shao, L., Zhang, D., Ro, C.-U., Hu, M., Bi, X., Geng, H., Matsuki, A., Niu, H., and Chen, J.: A review of single aerosol particle studies in the atmosphere of East Asia: morphology, mixing state, source, and heterogeneous reactions, J. Clean. Prod., 112, 1330-1349, https://doi.org/10.1016/j.jclepro.2015.04.050, 2016a.

Li, W., Sun, J., Xu, L., Shi, Z., Riemer, N., Sun, Y., Fu, P., Zhang, J., Lin, Y., Wang, X., Shao, L., Chen, J., Zhang, X., Wang, Z., and Wang, W.: A conceptual framework for mixing structures in individual aerosol particles, J. Geophys. Res.-Atmos., 121, 1378413798, https://doi.org/10.1002/2016jd025252, 2016 b.

Li, W., Xu, L., Liu, X., Zhang, J., Lin, Y., Yao, X., Gao, H., Zhang, D., Chen, J., Wang, W., Harrison, R. M., Zhang, X., Shao, L., Fu, P., Nenes, A., and Shi, Z.: Air pollution-aerosol interactions produce more bioavailable iron for ocean ecosystems, Sci. Adv., 3, e1601749, https://doi.org/10.1126/sciadv.1601749, 2017c.

Li, Z., Lee, K.-H., Wang, Y., Xin, J., and Hao, W.-M.: First observation-based estimates of cloud-free aerosol radiative forcing across China, J. Geophys. Res.-Atmos., 115, D00K18, https://doi.org/10.1029/2009jd013306, 2010.

Li, Z., Guo, J., Ding, A., Liao, H., Liu, J., Sun, Y., Wang, T., Xue, H., Zhang, H., and Zhu, B.: Aerosol and boundary-layer interactions and impact on air quality, Natl. Sci. Rev., 4, 810-833, https://doi.org/10.1093/nsr/nwx117, 2017b.

Liu, L., Zhang, J., Zhang, Y., Wang, Y., Xu, L., Yuan, Q., Liu, D., Sun, Y., Fu, P., Shi, Z., and Li, W.: Persistent residential burningrelated primary organic particles during wintertime hazes in North China: insights into their aging and optical changes, Atmos. Chem. Phys., 21, 2251-2265, https://doi.org/10.5194/acp21-2251-2021, 2021.

Liu, S., Aiken, A. C., Gorkowski, K., Dubey, M. K., Cappa, C. D., Williams, L. R., Herndon, S. C., Massoli, P., Fortner, E. C., Chhabra, P. S., Brooks, W. A., Onasch, T. B., Jayne, J. T., Worsnop, D. R., China, S., Sharma, N., Mazzoleni, C., Xu, L., Ng, N. L., Liu, D., Allan, J. D., Lee, J. D., Fleming, Z. L., Mohr, C., Zotter, P., Szidat, S., and Prévôt, A. S. H.: Enhanced light absorption by mixed source black and brown carbon particles in UK winter, Nat. Commun., 6, 8435, https://doi.org/10.1038/ncomms9435, 2015.

Liu, Z., Hu, B., Zhang, J., Yu, Y., and Wang, Y.: Characteristics of aerosol size distributions and chemical compositions during wintertime pollution episodes in Beijing, Atmos. Res., 168, 112, https://doi.org/10.1016/j.atmosres.2015.08.013, 2016.

Meng, Z. Y., Ding, G. A., Xu, X. B., Xu, X. D., Yu, H. Q., and Wang, S. F.: Vertical distributions of $\mathrm{SO}_{2}$ and $\mathrm{NO}_{2}$ in the lower atmo- 
sphere in Beijing urban areas, China, Sci. Total Environ., 390, 456-465, https://doi.org/10.1016/j.scitotenv.2007.10.012, 2008.

Merikallio, S., Lindqvist, H., Nousiainen, T., and Kahnert, M.: Modelling light scattering by mineral dust using spheroids: assessment of applicability, Atmos. Chem. Phys., 11, 5347-5363, https://doi.org/10.5194/acp-11-5347-2011, 2011.

Müller, A., Miyazaki, Y., Aggarwal, S. G., Kitamori, Y., Boreddy, S. K. R., and Kawamura, K.: Effects of chemical composition and mixing state on size-resolved hygroscopicity and cloud condensation nuclei activity of submicron aerosols at a suburban site in northern Japan in summer, J. Geophys. Res.-Atmos., 122, 93019318, https://doi.org/10.1002/2017jd027286, 2017.

Niu, H., Shao, L., and Zhang, D.: Soot particles at an elevated site in eastern China during the passage of a strong cyclone, Sci. Total Environ., 430, 217-222, https://doi.org/10.1016/j.scitotenv.2012.04.050, 2012.

Niu, H., Hu, W., Zhang, D., Wu, Z., Guo, S., Pian, W., Cheng, W., and Hu, M.: Variations of fine particle physiochemical properties during a heavy haze episode in the winter of Beijing, Sci. Total Environ., 571, 103-109, https://doi.org/10.1016/j.scitotenv.2016.07.147, 2016.

Peng, J., Hu, M., Guo, S., Du, Z., Zheng, J., Shang, D., Levy Zamora, M., Zeng, L., Shao, M., Wu, Y. S., Zheng, J., Wang, Y., Glen, C. R., Collins, D. R., Molina, M. J., and Zhang, R.: Markedly enhanced absorption and direct radiative forcing of black carbon under polluted urban environments, P. Natl. Acad Sci. USA, 113, 4266-4271, https://doi.org/10.1073/pnas.1602310113, 2016.

Petaja, T., Jarvi, L., Kerminen, V. M., Ding, A. J., Sun, J. N., Nie, W., Kujansuu, J., Virkkula, A., Yang, X. Q., Fu, C. B., Zilitinkevich, S., and Kulmala, M.: Enhanced air pollution via aerosol-boundary layer feedback in China, Sci. Rep., 6, 18998, https://doi.org/10.1038/srep18998, 2016.

Platis, A., Altstädter, B., Wehner, B., Wildmann, N., Lampert, A., Hermann, M., Birmili, W., and Bange, J.: An Observational Case Study on the Influence of Atmospheric Boundary-Layer Dynamics on New Particle Formation, Bound.-Lay. Meteorol., 158, 6792, https://doi.org/10.1007/s10546-015-0084-y, 2015.

Qi, X., Ding, A., Nie, W., Chi, X., Huang, X., Xu, Z., Wang, T., Wang, Z., Wang, J., Sun, P., Zhang, Q., Huo, J., Wang, D., Bian, Q., Zhou, L., Zhang, Q., Ning, Z., Fei, D., Xiu, G., and $\mathrm{Fu}, \mathrm{Q}$.: Direct measurement of new particle formation based on tethered airship around the top of the planetary boundary layer in eastern China, Atmos. Environ., 209, 92-101, https://doi.org/10.1016/j.atmosenv.2019.04.024, 2019.

Ramanathan, V., Crutzen, P. J., Mitra, A. P., and Sikka, D.: The Indian Ocean Experiment and the Asian Brown Cloud, Curr. Sci., 83, 947-955, 2002.

Rodriguez-Navarro, C., di Lorenzo, F., and Elert, K.: Mineralogy and physicochemical features of Saharan dust wet deposited in the Iberian Peninsula during an extreme red rain event, Atmos. Chem. Phys., 18, 10089-10122, https://doi.org/10.5194/acp-1810089-2018, 2018

Saliba, G., Subramanian, R., Saleh, R., Ahern, A. T., Lipsky, E. M., Tasoglou, A., Sullivan, R. C., Bhandari, J., Mazzoleni, C., and Robinson, A. L.: Optical properties of black carbon in cookstove emissions coated with secondary organic aerosols: Measurements and modeling, Aerosol. Sci. Tech., 50, 1264-1276, https://doi.org/10.1080/02786826.2016.1225947, 2016.
Scarnato, B. V., Vahidinia, S., Richard, D. T., and Kirchstetter, T. W.: Effects of internal mixing and aggregate morphology on optical properties of black carbon using a discrete dipole approximation model, Atmos. Chem. Phys., 13, 5089-5101, https://doi.org/10.5194/acp-13-5089-2013, 2013.

Schneider, C. A., Rasband, W. S., and Eliceiri, K. W.: NIH Image to ImageJ: 25 years of image analysis, N. Methods, 9, 671-675, https://doi.org/10.1038/nmeth.2089, 2012.

Shao, L., Hou, C., Geng, C., Liu, J., Hu, Y., Wang, J., Jones, T., Zhao, C., and BéruBé, K.: The oxidative potential of $\mathrm{PM}_{10}$ from coal, briquettes and wood charcoal burnt in an experimental domestic stove, Atmos. Environ., 127, 372-381, https://doi.org/10.1016/j.atmosenv.2015.12.007, 2016.

Shao, L., Hu, Y., Shen, R., Schafer, K., Wang, J., Wang, J., SchnelleKreis, J., Zimmermann, R., BeruBe, K., and Suppan, P.: Seasonal variation of particle-induced oxidative potential of airborne particulate matter in Beijing, Sci. Total Environ., 579, 1152-1160, https://doi.org/10.1016/j.scitotenv.2016.11.094, 2017.

Sharma, N., China, S., Bhandari, J., Gorkowski, K., Dubey, M., Zaveri, R. A., and Mazzoleni, C.: Physical Properties of Aerosol Internally Mixed With Soot Particles in a Biogenically Dominated Environment in California, Geophys. Res. Lett., 45, 11473 411482, https://doi.org/10.1029/2018gl079404, 2018.

Shi, Z., Vu, T., Kotthaus, S., Harrison, R. M., Grimmond, S., Yue, S., Zhu, T., Lee, J., Han, Y., Demuzere, M., Dunmore, R. E., Ren, L., Liu, D., Wang, Y., Wild, O., Allan, J., Acton, W. J., Barlow, J., Barratt, B., Beddows, D., Bloss, W. J., Calzolai, G., Carruthers, D., Carslaw, D. C., Chan, Q., Chatzidiakou, L., Chen, Y., Crilley, L., Coe, H., Dai, T., Doherty, R., Duan, F., Fu, P., Ge, B., Ge, M., Guan, D., Hamilton, J. F., He, K., Heal, M., Heard, D., Hewitt, C. N., Hollaway, M., Hu, M., Ji, D., Jiang, X., Jones, R., Kalberer, M., Kelly, F. J., Kramer, L., Langford, B., Lin, C., Lewis, A. C., Li, J., Li, W., Liu, H., Liu, J., Loh, M., Lu, K., Lucarelli, F., Mann, G., McFiggans, G., Miller, M. R., Mills, G., Monk, P., Nemitz, E., O’Connor, F., Ouyang, B., Palmer, P. I., Percival, C., Popoola, O., Reeves, C., Rickard, A. R., Shao, L., Shi, G., Spracklen, D., Stevenson, D., Sun, Y., Sun, Z., Tao, S., Tong, S., Wang, Q., Wang, W., Wang, X., Wang, X., Wang, Z., Wei, L., Whalley, L., Wu, X., Wu, Z., Xie, P., Yang, F., Zhang, Q., Zhang, Y., Zhang, Y., and Zheng, M.: Introduction to the special issue "In-depth study of air pollution sources and processes within Beijing and its surrounding region (APHH-Beijing)", Atmos. Chem. Phys., 19, 7519-7546, https://doi.org/10.5194/acp19-7519-2019, 2019.

Shou, Y., Huang, Y., Zhu, X., Liu, C., Hu, Y., and Wang, H.: A review of the possible associations between ambient $\mathrm{PM}_{2.5}$ exposures and the development of Alzheimer's disease, Ecotoxicol. Environ. Saf., 174, 344-352, https://doi.org/10.1016/j.ecoenv.2019.02.086, 2019.

Sorensen, C. M.: Light Scattering by Fractal Aggregates: A Review, Aerosol. Sci. Tech., 35, 648-687, 2001.

Sun, Y., Zhuang, G., Tang, A., Wang, Y., and An, Z.: Chemical Characteristics of $\mathrm{PM}_{2.5}$ and $\mathrm{PM}_{10}$ in Haze-Fog Episodes in Beijing, Environ. Sci. Technol., 40, 3148-3155, https://doi.org/10.1021/es051533g, 2006.

Sun, Y., Jiang, Q., Wang, Z., Fu, P., Li, J., Yang, T., and Yin, Y.: Investigation of the sources and evolution processes of severe haze pollution in Beijing in January 2013, J. Geophys.-Res.-Atmos., 119, 4380-4398, https://doi.org/10.1002/2014jd021641, 2014. 
Sun, Y., Du, W., Wang, Q., Zhang, Q., Chen, C., Chen, Y., Chen, Z., Fu, P., Wang, Z., Gao, Z., and Worsnop, D. R.: Real-Time Characterization of Aerosol Particle Composition above the Urban Canopy in Beijing: Insights into the Interactions between the Atmospheric Boundary Layer and Aerosol Chemistry, Environ. Sci. Technol., 49, 11340-11347, https://doi.org/10.1021/acs.est.5b02373, 2015.

Sun, Y., Du, W., Fu, P., Wang, Q., Li, J., Ge, X., Zhang, Q., Zhu, C., Ren, L., Xu, W., Zhao, J., Han, T., Worsnop, D. R., and Wang, Z.: Primary and secondary aerosols in Beijing in winter: sources, variations and processes, Atmos. Chem. Phys., 16, 8309-8329, https://doi.org/10.5194/acp-16-8309-2016, 2016.

Sun, Y. L., Wang, Z. F., Fu, P. Q., Yang, T., Jiang, Q., Dong, H. B., Li, J., and Jia, J. J.: Aerosol composition, sources and processes during wintertime in Beijing, China, Atmos. Chem. Phys., 13, 4577-4592, https://doi.org/10.5194/acp-13-4577-2013, 2013.

Tang, M., Cziczo, D. J., and Grassian, V. H.: Interactions of Water with Mineral Dust Aerosol: Water Adsorption, Hygroscopicity, Cloud Condensation, and Ice Nucleation, Chem. Rev., 116, 4205-4259, https://doi.org/10.1021/acs.chemrev.5b00529, 2016.

Tao, J., Zhang, L., Cao, J., and Zhang, R.: A review of current knowledge concerning $\mathrm{PM}_{2.5}$ chemical composition, aerosol optical properties and their relationships across China, Atmos. Chem. Phys., 17, 9485-9518, https://doi.org/10.5194/acp-179485-2017, 2017.

Unga, F., Choël, M., Derimian, Y., Deboudt, K., Dubovik, O., and Goloub, P.: Microscopic Observations of Core-Shell Particle Structure and Implications for Atmospheric Aerosol Remote Sensing, J. Geophys. Res.-Atmos., 123, 13944-913962, https://doi.org/10.1029/2018jd028602, 2018.

Wang, G., Zhang, R., Gomez, M. E., Yang, L., Levy Zamora, M., Hu, M., Lin, Y., Peng, J., Guo, S., Meng, J., Li, J., Cheng, C., Hu, T., Ren, Y., Wang, Y., Gao, J., Cao, J., An, Z., Zhou, W., Li, G., Wang, J., Tian, P., Marrero-Ortiz, W., Secrest, J., Du, Z., Zheng, J., Shang, D., Zeng, L., Shao, M., Wang, W., Huang, Y., Wang, Y., Zhu, Y., Li, Y., Hu, J., Pan, B., Cai, L., Cheng, Y., Ji, Y., Zhang, F., Rosenfeld, D., Liss, P. S., Duce, R. A., Kolb, C. E., and Molina, M. J.: Persistent sulfate formation from London Fog to Chinese haze, P. Natl. Acad Sci. USA, 113, 13630-13635, https://doi.org/10.1073/pnas.1616540113, 2016.

Wang, Q., Sun, Y., Xu, W., Du, W., Zhou, L., Tang, G., Chen, C., Cheng, X., Zhao, X., Ji, D., Han, T., Wang, Z., Li, J., and Wang, Z.: Vertically resolved characteristics of air pollution during two severe winter haze episodes in urban Beijing, China, Atmos. Chem. Phys., 18, 2495-2509, https://doi.org/10.5194/acp18-2495-2018, 2018.

Wang, W., Shao, L., Guo, M., Hou, C., Xing, J., and Wu, F.: Physicochemical Properties of Individual Airborne Particles in Beijing during Pollution Periods, Aerosol. Air Qual. Res., 17, 32093219, https://doi.org/10.4209/aaqr.2017.03.0116, 2017.

Wang, X., Cotter, E., Iyer, K. N., Fang, J., Williams, B. J., and Biswas, P.: Relationship between pyrolysis products and organic aerosols formed during coal combustion, P. Combust. Inst., 35, 2347-2354, https://doi.org/10.1016/j.proci.2014.07.073, 2015.

Wang, Y., Yao, L., Wang, L., Liu, Z., Ji, D., Tang, G., Zhang, J., Sun, Y., Hu, B., and Xin, J.: Mechanism for the formation of the January 2013 heavy haze pollution episode over central and eastern China, Sci. China Earth Sci., 57, 14-25, https://doi.org/10.1007/s11430-013-4773-4, 2013.
Wehner, B., Siebert, H., Ansmann, A., Ditas, F., Seifert, P., Stratmann, F., Wiedensohler, A., Apituley, A., Shaw, R. A., Manninen, H. E., and Kulmala, M.: Observations of turbulenceinduced new particle formation in the residual layer, Atmos. Chem. Phys., 10, 4319-4330, https://doi.org/10.5194/acp-104319-2010, 2010.

Xia, Y., Guan, D., Meng, J., Li, Y., and Shan, Y.: Assessment of the pollution-health-economics nexus in China, Atmos. Chem. Phys., 18, 14433-14443, https://doi.org/10.5194/acp-18-144332018, 2018.

Xu, L., Liu, L., Zhang, J., Zhang, Y., Ren, Y., Wang, X., and Li, W.: Morphology, Composition, and Mixing State of Individual Aerosol Particles in Northeast China during Wintertime, Atmosphere, 8, 47, https://doi.org/10.3390/atmos8030047, 2017.

$\mathrm{Xu}$, L., Zhang, D., and Li, W.: Microscopic comparison of aerosol particles collected at an urban site in North China and a coastal site in Japan, Sci. Total Environ., 669, 948-954, https://doi.org/10.1016/j.scitotenv.2019.03.163, 2019.

Yuan, Q., Li, W., Zhou, S., Yang, L., Chi, J., Sui, X., and Wang, W.: Integrated evaluation of aerosols during haze-fog episodes at one regional background site in North China Plain, Atmos. Res., 156, 102-110, https://doi.org/10.1016/j.atmosres.2015.01.002, 2015.

Zhang, D., Chen, B., Yamada, M., Niu, H., Wang, B., Iwasaka, Y., and Shi, G.: Elevated soot layer in polluted atmosphere: A case study in Beijing, J. Meteorol. Soc. Jpn., 90, 361-375, https://doi.org/10.2151/jmsj.2012-302, 2012.

Zhang, J., Liu, L., Wang, Y., Ren, Y., Wang, X., Shi, Z., Zhang, D., Che, H., Zhao, H., Liu, Y., Niu, H., Chen, J., Zhang, X., Lingaswamy, A. P., Wang, Z., and Li, W.: Chemical composition, source, and process of urban aerosols during winter haze formation in Northeast China, Environ. Pollut., 231, 357-366, https://doi.org/10.1016/j.envpol.2017.07.102, 2017.

Zhang, J., Liu, L., Xu, L., Lin, Q., Zhao, H., Wang, Z., Guo, S., Hu, M., Liu, D., Shi, Z., Huang, D., and Li, W.: Exploring wintertime regional haze in northeast China: role of coal and biomass burning, Atmos. Chem. Phys., 20, 5355-5372, https://doi.org/10.5194/acp-20-5355-2020, 2020.

Zhang, Q., Ma, X., Tie, X., Huang, M., and Zhao, C.: Vertical distributions of aerosols under different weather conditions: Analysis of in-situ aircraft measurements in Beijing, China, Atmos. Environ., 43, 5526-5535, https://doi.org/10.1016/j.atmosenv.2009.05.037, 2009.

Zhou, W., Sun, Y., Xu, W., Zhao, X., Wang, Q., Tang, G., Zhou, L., Chen, C., Du, W., Zhao, J., Xie, C., Fu, P., and Wang, Z.: Vertical Characterization of Aerosol Particle Composition in Beijing, China: Insights From 3-Month Measurements With Two Aerosol Mass Spectrometers, J. Geophys. Res.-Atmos., 123, 13016-13029, https://doi.org/10.1029/2018jd029337, 2018a.

Zhou, W., Wang, Q., Zhao, X., Xu, W., Chen, C., Du, W., Zhao, J., Canonaco, F., Prévôt, A. S. H., Fu, P., Wang, Z., Worsnop, D. R., and Sun, Y.: Characterization and source apportionment of organic aerosol at $260 \mathrm{~m}$ on a meteorological tower in Beijing, China, Atmos. Chem. Phys., 18, 3951-3968, https://doi.org/10.5194/acp-18-3951-2018, 2018 b.

Zhu, J., Crozier, P. A., and Anderson, J. R.: Characterization of light-absorbing carbon particles at three altitudes in East Asian outflow by transmission electron microscopy, Atmos. Chem. Phys., 13, 6359-6371, https://doi.org/10.5194/acp-136359-2013, 2013. 